\title{
THE AUTOBIOGRAPHICAL PROVOCATION: WITOLD GOMBROWICZ'S DIARY AS A TRANSFORMATIVE TEXT
}

\section{Forms of Autobiographical Writing}

An author's name on autobiographical texts has a different status from its presence on works of fiction because we tend to regard the former as more firmly bound with reference, with more essential ties to the author and real events. According to Paul de Man, we endow writers of autobiographical genres with ontological identity that gives their texts contractual authority, rather than representational and cognitive identity rooted in tropes, as in fictional texts: we perceive these genres as speech acts that substantiate the author's contractual claim, and read them as verification of the validity of the contract and authenticity of the author's signature on it. ${ }^{1}$ De Man questions the belief that life inevitably produces autobiography, and asks whether writing about oneself is not 'in fact governed by the technical demands of self-portraiture and thus determined, in all its aspects, by the resources of [one's] medium?'2 He argues that autobiographical genres offer neither a reliable body of knowledge to readers nor a definitive means of self-presentation to writers, as they cannot eliminate fictionality and provide closure and totalization. ${ }^{3}$ Unable to escape the tropological language of substitutions that haunts all literary texts, these genres cannot make language and what it names coincide.

Do all autobiographical texts try to eliminate fictionality, as de Man proposes? Although the mind that the autobiographical project is set to expose is indeed shaped by this project, the goal of autobiographical writing is not always self-portraiture, nor is the main concern necessarily the circumvention of linguistic constraints. Witold Gombrowicz's Diary shows that not all autobiographical texts form an autobiographical pact with the reader, based on the understanding that any autobiographical type of writing should be closely tied to the author as a real person and to real events that this person experiences. Gombrowicz is not alone in this regard. Other twentieth-century autobiographical literary texts depart from what used to be the established convention. André Gide's diaries are an exemplary early case. More than chronicles of what happened to the writer or an account of who he is, Gide's diaries are works of literary creation which go beyond straightforward records of facts and unstylized intimate confessions. Roland Barthes observes that Gide's diaries contain 'sentences which are halfway between confession and creation': 'They are no longer completely Gide; they begin to be outside him,

${ }^{1}$ Paul de Man, 'Autobiography as De-facement', $M L N$, 94 (1979), 919-30 (p. 922).

2 Ibid., p. 920.

3 Ibid., p. 921. 
en route for some unspecified work in which they want to appear, which they summon into being.' 4 Similarly, Justin O'Brien points out the affinity between the type of writing in Gide's diary and that found in his fiction: 'the journal is Gide's form par excellence and his imaginative works might almost be considered to be extracted from his own Journals'. 5 A later example of an autobiographical text that does not shy away from literary writing is Jerzy Andrzejewski's Pulp (Miazga). Andrzejewski announces that his goal is not to set the record straight: 'I do not write to clarify life and offer a neat explanation of it; on the contrary, I write to complicate life. ${ }^{6}$ He does so by combining the form of the diary with fictionalized narrative passages about the writer Nagórski in a way that is not a mere juxtaposition of the two. In Pulp the boundary between diary and fiction is unstable-Andrzejewski speaks of a 'mashed content [miazgowatej treści]'-because Nagórski is an unmistakably autobiographical character, a proxy for Andrzejewski to work through some of his own perceived shortcomings. ${ }^{7}$ Another later example of an autobiographical prose work that includes fictional elements as an instrument for complicating the record and decentring the writing self is Bohumil Hrabal's trilogy In-House Weddings, Vita Nuova, and Gaps. Hrabal achieves this complication and decentring by adopting a narrative mask for his autobiography: although he tells the story in the first person, the narrator is his wife. ${ }^{8}$

Examples could be further multiplied. My point is not to posit an alternative tradition of writers who opposed the established convention in autobiographical writing - the examples cited are too heterogeneous for that. My point is more modest: to draw attention to diverse forms of stylized autobiographical texts and to examine one in detail. What these texts have in common is that they are not just manifestations of the logical possibility implied in de Man's argument, that autobiographical texts can never successfully evade fictionality. These texts are instances of a deliberate choice on the part of the writer not to evade it. Their different techniques of transposition allow the writer to question himself in a fashion that is simultaneously more methodical and less predictable than in conventional autobiographies. Creative, provocative, and even imaginary elements in these texts enable the writers to present and inspect their self from a wide-ranging set of perspectives, thereby not only

4 Roland Barthes, 'On Gide and his Journal', in A Barthes Reader, ed. by Susan Sontag, trans. by Richard Howard (London: Cape, 1982), pp. 3-17 (p. 4).

5 Justin O'Brien, The French Literary Horizon (New Brunswick: Rutgers University Press, 1967), p. 92.

6 Jerzy Andrzejewski, Miazga (London: Polonia Book Fund, 1981), p. 20 (my translation).

7 Jerzy Andrzejewski, 'Rozmowa z Andrzejem Mencwelem' (1981); cited in Teatr Polski we Wrocławiu: Jerzy Andrzejewski, 'Miazga', ed. by Maria Dębicz (Wrocław: Instytut Teatralny, 1991), p. 18 (my translation).

${ }^{8}$ Bohumil Hrabal, Autobiografická trilogie, in Hrabal, Spisy, ed. by Václav Kadlec and Jiří Pelán, 7 vols (Prague: Mladá Fronta, 2014- ), v (2016). 
communicating who they are and what they did, but also shaping who they become.

The practice in autobiographical writing of shaping the self rather than representing it in a mimetic fashion appears in a variety of twentieth-century and contemporary autobiographical texts that have been widely discussed in academic circles. The main premiss of these discussions is that the distinction between the author and the narrator applies to autobiographical texts as much as to fictional ones. The narrator in autobiographical texts is also, though arguably to a lesser degree than in works of fiction, a construct that is never fully identical with the author. Paul John Eakin argues that many twentieth-century autobiographical texts question the traditional notion of autobiographical truth as a fixed content and emphasize instead the unavoidable fictionality of any writing about oneself. ${ }^{9}$ More recently, the debate has shifted to the notion of 'autofiction': a type of retrospective narrative of one's life that focuses on a part of it, or discrete fragments of it, and that is told in a non-linear fashion rather than as a continuous story of one's life as a whole, as in traditional autobiography. Jacques Lecarme defines autofiction as 'a narrative in which the author, the narrator and the protagonist share the same nominal identity and in which the generic title indicates that it is a novel'. ${ }^{10}$ Since autofiction brings together the referential and the fictional in a single narrative voice, Lecarme claims that an autofictional pact must be contradictory', for unlike the autobiographical pact, to which I shall return later, the author of autofictions does not commit to objective truth. ${ }^{11}$ One does not have to go as far as Chloé Delaume, who regards the pact between the author and the reader in autofiction as a lie-'The author is committed to one thing only: to lie to the reader' - but it is certainly the case that readers of autofictions are more sympathetic to creative transposition than readers of traditional autobiographies. ${ }^{12}$ Critics have also pointed out that the element of fiction in autofiction offers a safer environment for authors to tackle their past than traditional autobiographies. Karen Ferreira-Meyers argues that fictive components in autofiction, which are present either directly in the text or in the peritextual elements, such as the title, the introduction, or the back cover, protect the author, thereby allowing him/her to write about the self and about others with less danger than in autobiography, for after all we are told that it is partly fictional. ${ }^{13}$ This sense of protection can potentially generate therapeutic effects. In autofiction, but also in fictional autobiography, as Celia

\footnotetext{
9 Paul John Eakin, Fictions in Autobiography: Studies in the Art of Self-Invention (Princeton: Princeton University Press, 1985), p. 7.

${ }^{10}$ Jacques Lecarme, 'L'Autofiction: un mauvais genre?', in Autofictions et cie, ed. by Serge Doubrovsky and others (Paris: Université de Paris, 1993), pp. 227-49 (p. 227, my translation).

${ }^{11}$ Ibid., p. 242 (my translation).

${ }^{12}$ Chloé Delaume, La Règle du je: autofiction. Un essai (Paris: PUF, 2010), p. 67 (my translation).

13 Karen Ferreira-Meyers, 'Autobiography and Autofiction', in Writing the Self: Essays on Auto-
} 
Hunt emphasizes, imaginative writing about oneself is a reflexive tool that facilitates 'a deeper engagement with the self': it can produce a healing effect of making us recognize the fictionality of the stories that we tell ourselves to feel more secure and that we might start to depend on less in the future. ${ }^{14}$

Gombrowicz's Diary fits into these discussions in a number of ways. First, it is its genre that is of interest, as most of the contemporary debate about autobiographies and autofictions has been about narratives. Although the notion of autofiction is theoretically open to other genres apart from narratives, it has been discussed almost exclusively in terms of personally inspired literary storytelling. In other words, what has been emphasized is the retrospective nature of the narrative act in autobiographical writing, which applies to the genre of the diary only to a small degree. Second, while the Diary contains the same elements of self-distancing, self-repositioning, and even 'fiction' as in autofictions, the role of these elements is different because the text is not designated as fictional. This challenges the idea of protection and safety associated with autofiction as well as the concomitant effects of deeper connection and self-therapy. And third, unlike more traditional autobiographical writing that aims at telling the truth about the self but inexorably falls short of it on account of the ontological disposition of the self and of language, the Diary deliberately takes an approach to writing about the self that is creative and is meant to destabilize the self. In the Diary, de Man's argument that the author's signature on autobiographical writing, which indicates a single subject but which in reality is 'folded back upon itself in mirror-like self-understanding', is an obvious fact, not a revelation of some hidden truth about this writing. ${ }^{15}$ What is more, this fact is a catalyst of Gombrowicz's autobiographical project, not a hindrance to it. The issue in the Diary is not whether the literary medium restricts the self that writes about itself, thereby determining how it appears in the text. Rather, the issue is how this medium can be used to provoke the self and elicit new reactions from it.

\section{The Self in Gombrowicz's 'Diary'}

Written in emigration between 1953 and 1969 (mostly in Argentina and later in Germany and France) and published in short instalments during the same period in the Polish monthly Kultura, 'The Fragments of Diary', as the Diary was originally entitled, was a controversial contribution to this Paris-based journal. Not only was Gombrowicz relatively unknown, but even for those

biography and Autofiction, ed. by Kerstin W. Shands and others (Huddinge: Södertörn University Press, 2015), pp. 203-18 (pp. 208-09).

${ }^{14}$ Celia Hunt, 'Therapeutic Effects of Writing Fictional Autobiography', Life Writing, 7 (2010), 231-44 (p. 235).

15 De Man, 'Autobiography as De-facement', p. 923. 
who were familiar with his first novel and collection of short stories, Gombrowicz's sarcasm about Polish patriotism and cultural narrow-mindedness in these texts made him a questionable contributor to this high-profile émigré outlet. Gombrowicz was unlikely to fulfil the expectation of Polish readers that at a time of national crisis, such as the Communist dictatorship in Poland, writers have a duty to become the nation's spiritual leaders, rallying people behind their common history and cultural heritage. ${ }^{16}$ The editor of Kultura, Jerzy Giedroyc, knew that this expectation would not be met. Gombrowicz made it clear to him that his aspiration in writing the Diary was personal: 'to create Gombrowicz the thinker, Gombrowicz the cultural demonologist, and many other necessary Gombrowiczes'. ${ }^{17}$

At the beginning of the Diary Gombrowicz declares that all 'serious art [must be] the voice of the individual, the expression of a person in the singular [wyrazicielem człowieka $w$ liczbie pojedynczej]'. ${ }^{18}$ The Diary is supposed to be this voice, but Gombrowicz acknowledges that he has not found it yet:

I want to be myself. Yes, even though I know that there is nothing more misleading than that inaccessible 'I', I know, too, that all the honor and value of life depend on the relentless pursuit of and the relentless defense of the 'I'. ( $D$, p. 239)

To find his singular voice, he proposes the reductive method of 'a more and more distinct delineation [wyraźniejszego ustalenia] of my own I' ( $D$, p. 112). Instead of adding information about himself and composing an increasingly detailed self-image, he wants to eradicate everything that does not originate in himself, as the following mental exercise illustrates:

First, push away all the things that make everything easier, find yourself in a cosmos that is as bottomless as you can stand, in a cosmos at the limits of your consciousness, and experience a condition where you are left to your own loneliness and your own strength, only then, when the abyss which you have not managed to tame throws you from the saddle, sit down on the earth and discover the sand and grass anew. $(D$, p. 219)

Although this exercise is an instruction addressed to the reader, Gombrowicz directs a similar call to himself: 'Narrow myself! Limit myself! To live only with what is mine!' ( $D$, p. 350). Coming later in the text, this call reveals that

\footnotetext{
${ }^{16}$ For a discussion of these expectations see Jerzy Jarzębski, 'Być wieszczem', in Powieść jako autokreacja (Kraków and Wrocław: Wydawnictwo Literackie, 1984), pp. 133-69; Beth Holmgren, 'Witold Gombrowicz within the Wieszcz Tradition', Slavic and East European Journal, 33 (1989), 556-70.

17 Witold Gombrowicz, 'Letter to Giedroyc' (1952); cited in Rita Gombrowicz, 'Foreword', in Witold Gombrowicz, Diary, trans. by Lillian Vallee (New Haven: Yale University Press, 2012), pp. vii-x (p. viii).

18 Witold Gombrowicz, Diary (see previous note), p. 22; further references to this edition will be given in the text identified by the abbreviation $D$. English translations are modified to follow more closely the Polish original, Dziennik 1953-1969 (Kraków: Wydawnictwo Literackie, 2007).
} 
he is still looking for his voice. While he knows that this process cannot be carried through to any definitive completion, he is nonetheless dissatisfied with what he has done so far. He must repeat the self-reductive procedure, though it is not clear at this point whether this is because, like everyone else, he has a tendency to return to the saddle that makes things easier, or because he cannot go far enough all at once in the direction of self-delineation.

Gombrowicz's objective is 'to be a concrete man. To be an individual' ( $D$, p. 110). Ten years into his project, however, he starts questioning the viability of this objective:

You strive for many long years to be somebody-and what do you become? A river of events in the present, a turbulent stream of facts, happening now, at this cold moment that you are experiencing and you can relate to nothing else. Confusion-only this is yours. $(D$, p. 602)

Gombrowicz wants to find his individuality and personal voice, not to tell readers what he has already found. Yet even this proves difficult to accomplish. Because the self is not a definite entity-'from time to time I am this or that' $(D$, p. 238) - the effect of demarcating it in the text is its further multiplication. The self-reductive procedure does not result in a distinct personality, but in more confusion. As the Diary progresses the problem of self-demarcation becomes increasingly prominent, not only with respect to attaining it, but also with respect to the opposite, namely being delineated too much:

I am. I am too much. And even though I could still do something unpredictable for myself, I no longer want to. I can't want because I am too much. Amid this indelineation, changeability, fluidity, under the ungraspable sky I am made, finished, delineated [określony]. (D, p. 211)

What complicates Gombrowicz's autobiographical project is not only the difficulty of executing it, but also its desirability. While self-delineation and singularity are the diarist's professed goals, they are also deplored because they immobilize him and limit his existential options.

The apparent contradiction in the Diary between the plan to delineate the self more distinctly and the despair over being delineated too much is a manifestation of the theme that is central to many writings by Gombrowicz: the conflict between Form and Chaos. As the narrator in the novel Ferdydurke laments: 'mankind is accursed because our existence on this earth does not tolerate any well-defined and stable hierarchy, everything continually flows, spills over, moves on, everyone must be aware of and be judged by everyone else'. ${ }^{19}$ Judgement introduces Form, which keeps the amorphous flow

19 Witold Gombrowicz, Ferdydurke, trans. by Danuta Borchardt (New Haven: Yale University Press, 2000), p. 5. 
of existence in check. It enforces habitual structures of thinking and acting that allow us to interact with each other more easily because instead of the multitude of personal peculiarities, we deal with common patterns. But Form also deforms us by obstructing our spontaneity and individuality. Stanisław Barańczak argues that for Gombrowicz the conflict between Form and Chaos is insoluble because each individual desires both the perfection of Form-that is, clarity of orientation in the world and a firm place vis-à-vis others-and the spontaneity of Chaos-that is, freedom of unpremeditated existence. ${ }^{20}$ Literature plays an important role in this conflict. Literature, by making this conflict visible, can at least partly contain it. The enemy of literary writing is not Form per se, as one cannot completely dispose of forms. The enemy is formalism, which freezes the conflict between Form and Chaos by insulating the former from the latter. ${ }^{21}$

The concrete individuality that Gombrowicz seeks to delineate in the Diary is not some undeformed self beyond Form. He maintains that Form deforms us, but, crucially, he does not believe in an undeformed self that was there before the deformation. His attempt to delineate his concrete individuality does not concern an undeformed self, but a self that is engaged in the struggle against deformation in full realization of both the artificiality of Form and the impossibility of bypassing it altogether. As he suggests in another autobiographical text, if the authentic self prior to deformation is out of our reach because we are never entirely free of social interaction, and consequently never outside Form, deformation is our only access to ourselves: 'I don't know who I am, but I suffer when I am deformed. So at least I know what I am not. My self is nothing but my will to be myself.'22 In the Diary Gombrowicz does not try to uncover the ultimate truth about himself that is hidden under the forms that deform him, for he does not think that such a truth exists. Instead of trying to convince others and himself of who he really is, the diarist brings to the fore the effects of deformation on himself: 'all the personal sore spots' $(D$, p. 112) that arise between him and other people as he battles for his individuality. But he does more. He intentionally provokes his artificialities and actively spoils his settled forms:

My truth and my strength rely on my endless spoiling of the game [...] I spoil my

${ }^{20}$ Stanisław Barańczak, 'Gombrowicz: Culture and Chaos', in 'Breathing under Water' and Other East European Essays (Cambridge, MA: Harvard University Press, 1990), pp. 95-106 (pp. 102-03).

${ }^{21}$ For this argument see Valérie Deshoulières, 'Witold Gombrowicz: pour une théorie romantique de l'inachèvement', Littérature, 97 (1995), 28-40 (p. 31).

${ }^{22}$ Witold Gombrowicz, A Kind of Testament, trans. by Alastair Hamilton (Philadelphia: Temple University Press, 1973), p. 77. Characteristically, Gombrowicz sardonically adds: 'A measly palliative! Another formula!' (ibid.). As we shall see later, Gombrowicz often questions his insights, not because they are incorrect or poorly expressed, but because language always runs the risk of relegating them to the status of clichés, and the process of thinking that has led to them to mere sound bites and catchphrases. 
elegance, I force myself to use other tactics, I change the situation for myself [psuje sobie szyki, zmuszam siebie do innych taktyk, zmieniam sobie sytuacje]. (D, p. 578)

This active approach of self-provocation and spoiling of Form throws the diarist off balance and gives him a unique perspective on himself. Describing this perspective as 'dialectical and full of antinomies' ( $D$, p. 300), Gombrowicz argues that it helps one to become 'conscious of one's internal contradictions and capable of exploiting them for one's own development [umiejacego wyzyskać ja dla rozwoju]' (D, p. 300). The Diary is not an instrument of self-decipherment. It is a tool for exploiting the unavoidable process of one's deformation for one's future development.

\section{The Genre and Style of the 'Diary'}

The Diary is a stylistically very idiosyncratic text, so much so that it has been called a quasi-diary and a hybrid diary. ${ }^{23}$ It retains the sense of immediacy and expressiveness that Bernard Duyfhuizen attributes to the genre of the diary, but otherwise it is a highly stylized piece of writing that incorporates a range of literary forms, including travelogue, political polemic, literary criticism, philosophical disputation, vignettes of stories, copies of letters, brief notations of daily trivia, and autobiographical passages that recount Gombrowicz's early years in Poland. ${ }^{24}$ The style, tone, and length of entries vary as well. The prevalent oral mode of telling, interspersed with question marks, commas, semicolons, and dashes, frequently turns into grammatically more complex structures and elaborate compositions. Tone ranges considerably too, from pensive to angry, as do the lengths of entries, running from a single phrase to many pages. Here are several examples:

\section{Thursday}

Cracow. Statues and palaces, which seem quite splendid to them but which to us, Italians, seem without great value. Galeazzo Ciano, Diary

Lechoń's article entitled 'Polish Literature and Literature in Poland' in Wiadomości. Is this really an honest piece of writing? His statements purport to show once again (yes, again!) that we are equal to the greatest world literatures, except that we are unknown and unappreciated. He writes (or says, rather, as this was a lecture given in New York for the local Polonia): 'Because our men of letters were preoccupied chiefly with things Polish, they could not fulfill the mission of designating the right place for our literature in the ranks of other literatures, or of establishing the world standing of our masterpieces.' (D, pp. 4-5)

23 Zdzisław Łapiński, 'Błazenada podszyta tragizmem', Plus Minus: dodatek tygodniowy Rzyczypospolitej, 37 (2000), 16-17 (p. 17); Jerzy Jarzębski, Podgladanie Gombrowicza (Kraków: Wydawnictwo Literackie, 2000), p. 187.

${ }^{24}$ Bernard Duyfhuizen, 'Diary Narratives in Fact and Fiction', Novel: Forum on Fiction, 19 (1986), 171-78 (pp. 176-77). 
Sunday

Tragedy.

I walked in the rain, hat perched over my forehead, collar raised, hands in my pockets. After which I returned home.

Then I went out again to get something to eat.

Then I ate it. $(D$, p. 85$)$

\section{Thursday}

In the dining car it is five in the afternoon, we are approaching Tandil, which is reminiscent of Salzburg from here-the slender tower of the church rising from the hills. Streams of spring light pour into space, the sun trembles in the air, color after color rises from the meadows until the last dispersion in the peripheries of the heavens. (D, p. 293)

\section{Monday}

Bach is boring! Objective. Abstract. Monotonous. Mathematical. Sublime. Cosmic. Cubic. Bach is boring! (D, p. 469)

The diversity of modes of writing in the Diary undermines Philippe Lejeune's argument that 'each diarist quickly settles into a small number of forms of language that become "molds" for all of his entries, and never deviates from them'. ${ }^{25}$ Gombrowicz uses a wide repertoire of forms with little regularity between the genre of each entry and its style, tone, and length. For instance, a pensive tone is not used exclusively for philosophical enquiries, which are often but not always long and grammatically complex, and personal anecdotes are not always short and stylistically plain. This lack of regular patterns challenges our reading habits. Not only do we encounter here something different from what is found in other diaries, but our expectations are also deflated as we go on with the reading. The stylistic and generic variations within the text make it difficult for us to form a stable idea about what we can expect from this particular diary as we read it.

The Diary offers a conflicting stance on literary style. Gombrowicz's professed goal is to 'elude style' ( $D$, p. 44) so as to minimize the effect of Form on the self and the text. However, to achieve this goal he alternates between genres, forms, and ways of writing so meticulously that he turns style, as a rhetorical figure used in the text, into a permanent fixture of this text. But perhaps this is a game of provocation as well. The claim to eliminate style while at the same time, paradoxically, being constantly preoccupied with it shows that the diarist knows that style-free writing is not a viable option. The Diary must be neither a product of pure artistic creation (a Form, a wellcomposed and finished work) nor a non-stylized record of raw facts (a Chaos of indiscriminate data). Gombrowicz's answer to this dual demand is irony. As was pointed out above, the diarist often subjects his observations to ironic

${ }^{25}$ Philippe Lejeune, On Diary, ed. by Jeremy D. Popkin and Julie Rak, trans. by Kathy Durnin (Honolulu: University of Hawaii Press, 2009), p. 180. 
exclamations that mock them as too formulaic. Another device that plays a similar role is the second voice. In the section devoted to a trip to Santiago del Estero, the diarist's voice splits into two: the first-person voice that has been the site of narrative so far, and another voice that interrupts the first, comments on its statements, and explicitly identifies their author as 'Gombrowicz'. For instance, after postulating a conceptual distinction between the notion of existence and that of life, the second voice interjects:

Thursday (So there, in the end, a redemptive thought came to him, an exchange of existence [that is, a formed life, just as man had made it] for that passively natural life, in its young, initial phase. This thought moved him quite perceptibly). (D, p. 391; parentheses and brackets original)

The function of the second voice is analogous to that of exclamations. In both cases, irony encourages a critical attitude and prevents the diarist's utterances from turning into clichés by putting the writer and the reader at a distance from the text.

Gombrowicz's combination of stylization with the literary effect of immediacy has proved difficult to categorize. Many critics and reviewers of the Diary have underscored either its factual side or its creative aspects. Lillian Vallee, for instance, describes it as 'a record' of Gombrowicz's survival. ${ }^{26}$ Those who have emphasized Diary's artistic aspirations have called it 'theatrical montage', or have likened it to a work of literary fiction by pointing out similarities between the diarist and narrators in Gombrowicz's novels. ${ }^{27}$ Konstanty Jeleński even classifies it as an autobiographical novel, with Susan Miron specifying that it is an autobiographical novel narrated by an unreliable narrator. ${ }^{28}$ Although the Diary provides valuable information about its author, it was not primarily a documentation of events. As Gombrowicz stresses in a letter to Giedroyc several years into the project, he has been composing it 'with more premeditation than it may appear'. ${ }^{29}$ At the same time, however, it is clearly not a work of fiction, not even an autobiographical novel or diary novel.

As in all factual (or actual) diaries, the mode of narrative in the Diary is segmented into a succession of consecutive units that are labelled with days and that interrupt the narrative and resume it on the next day or later. The same segmented structure applies to fictional (or fictive) diaries as well. In

${ }^{26}$ Lillian Vallee, 'Rich in Revolution: Witold Gombrowicz's Diary', World Literature Today, 61 (1987), 186-89 (p. 189).

${ }_{27}$ Piotr Florczyk, 'The Writer and the World: Review of Diary by Witold Gombrowicz', Michigan Quarterly Review, 52 (2013), 144-50 (p. 145); Jan Błoński, Forma, śmiech i rzeczy ostateczne: studia o Gombrowiczu (Kraków: Znak, 2003), p. 155.

${ }^{28}$ Konstanty Jeleński, 'Gombrowicz's Heroic Anti-Heroics', Formations, 1 (1985), 49-57 (p. 53); Susan Miron, 'Unreliable Narrator: Review of Diary. Volumes $1-3$ by Witold Gombrowicz', American Scholar, 63 (1994), 142-45 (p. 144).

29 Cited in Rita Gombrowicz, 'Foreword', p. viii. 
the diary novel, for example, as Gerald Prince describes it, narration does not take place at one sitting but is inserted between various sequences of events that are marked with days or dates. ${ }^{30}$ The segmented structure ties the diary more closely to the temporal present. This close link to the present is evident in factual diaries, in which even in cases where the diarist speaks about past events, the impression is that the narrative is happening in the present. But fictional diaries, such as the diary novel, produce this impression as well. Lorna Martens argues that the embeddedness of the diary novel in the present moment of writing is what separates it from adjacent genres, such as the memoir novel (which has an exclusively retrospective orientation and cares little for the present time of writing) and the epistolary novel (in which the impression is of writing that is taking place in the present moment, though that effect is achieved by the inclusion of the fictive reader of the letters in the text). ${ }^{31}$ One important difference between the factual and the fictional diary is that the latter often contains elements that identify it as fiction, such as, for example, the author's note at the beginning of Dostoevsky's Notes from Underground, which is already part of the text but is included before the diarist's first entry, and describes the work as a fictive diary. These elements are significant because they allow us to distinguish between the diarist in the text and the author of the actual manuscript. Although in both the factual and the fictional diary the future remains unknown, in the latter it is unknown only to the diarist in the text, not the producer of the manuscript.

Gombrowicz's Diary is not a diary novel because the author and the diarist are indistinguishable. It is also not a factual diary because even those parts that offer seemingly straightforward accounts of what has happened are stylized. Moreover, it is also not a notebook or a self-portrait. Although the genre of the notebook is similar to that of the diary in that both use a segmented structure, most notebooks ignore chronology, with many, such as Henry James's and even more so Albert Camus's and Walter Benjamin's, resembling working notebooks with quotations and sketches of ideas that show little concern for sequence. For a similar reason, the Diary is not a self-portrait, the designation given by Michel Beaujour to a version of autobiographical writing that relies on analogy and the thematic grouping of issues rather than continuous development. ${ }^{22}$ Unlike self-portraits, such as Michel Leiris's Rules of the Game, the Diary is firmly attached to chronology and continuity, albeit a chronology of the sequential order of dated entries, not one of retrospective self-presentation. But the Diary is no self-portrait for a more prosaic reason

\footnotetext{
30 Gerald Prince, 'The Diary Novel: Notes for the Definition of a Sub-Genre', Neophilologus, 59 (1975), 477-81 (p. 478).

${ }^{31}$ Lorna Martens, The Diary Novel (Cambridge: Cambridge University Press, 1985), pp. 4-5.

${ }^{32}$ Michel Beaujour, Poetics of the Literary Self-Portrait, trans. by Yara Milos (New York: New York University Press, 1991), p. 2.
} 
as well: it does not try to tell us who the author is. It neither narrates what the author has done nor describes who he is. The Diary is a distinctive type of autobiographical writing that heightens the focus of the text on the writing self while at the same time unsettling it. The segmented diary format anchors the text in the present moment, thereby bolstering its autobiographical expressivity and the sense of immediacy, but the formal experiments with style push it in the opposite direction of undermining self-expression and diluting autobiographical disclosure.

\section{Introspection, Intimacy, and the Self in Autobiographical Texts}

Originating in Rousseau's Confessions, the aim of modern autobiographical writing is the pursuit of a natural, unstylized, and transparent language that captures the self in its pure and undeformed state. This pursuit of 'total transparency and unmediated communication' turns to introspection as the path that will lead to the coveted purity of language and the self. ${ }^{33}$ In the Confessions introspection is carried out through Rousseau's recounting of his past wrongdoings. In contrast to Augustine's Confessions, in which the self was of no interest for its own sake but only as a site of repentance that leads to God's absolution, in Rousseau's text the self becomes the focal point. Paul de Man argues that in Rousseau the act of confessing is no longer a matter of ethics and religion, as it was for Augustine, but instead becomes an epistemological issue of inventing a language of truth and falsehood in which the writer finds important truths about himself as he conveys his transgressions. ${ }^{34}$

Despite this difference in purpose and technique, the ancient and early modern autobiographical projects nevertheless have one salient attribute in common: withdrawal into oneself as the path to a purer self (closer to God for Augustine, and closer to a socially unadulterated and natural self for Rousseau). What is problematic about this withdrawal, especially when it is enacted in writing, is its paradoxical consequences. The attempt to locate, uncover, and represent in the text a self that precedes social and cultural mediation, including literary mediation, ends in reusing these very mediations. As Michel Beaujour points out, at the place of one's innermost self one does not find purity and authenticity beyond the social and the cultural, but only fragments of culture. ${ }^{35}$ The presumed genuine self is an accumulation of ideas and ways of expression that have been recycled from even earlier thoughts, which one cannot entirely avoid reusing.

${ }^{33}$ Jean Starobinski, Jean-Jacques Rousseau: Transparency and Obstruction, trans. by Arthur Goldhammer (Chicago: University of Chicago Press, 1988), p. 153.

${ }^{34}$ Paul de Man, Allegories of Reading: Figural Language in Rousseau, Nietzsche, Rilke, and Proust (New Haven: Yale University Press, 1979), p. 279.

35 Beaujour, Poetics of the Literary Self-Portrait, p. 4. 
In Gombrowicz's Diary the principle of withdrawal is no longer the driving force of autobiographical writing. Instead of turning to introspection in search of authenticity and transparency, the diarist accepts the fact that the self is unstable and in a permanent state of change, and that literature is incapable of adequately representing it, as it cannot do away with the perpetual deferral of meaning that occurs as soon as one writes. The Diary's dual allegiance to the opposing principles of stylization and immediacy applies here as well. The text capitalizes on some aspects of the genre of the diary while challenging others. Like all diaries, the Diary presents the self in and through time rather than in a finished narrative. Robert A. Fothergill calls the diary 'serial autobiography' because the self that emerges in it has an aura of non-retrospective immediacy and has no knowledge of what is going to happen to it later. ${ }^{36}$ Stuart Sherman adds that this way of writing about oneself is markedly modern because it responds to the new perception of time as a homogeneous substance measured by the clock that is there waiting to be filled in: 'the uniform durations, provisionally blank, are seen by the diarist both to require filling (by experience in life, by inscription on the page) and also to facilitate it'. ${ }^{37}$ Gombrowicz commits to this modern activity of regular filling in time. However, even though he keeps to a form that is simultaneously cyclical and linear-as Felicity Nussbaum and Cynthia Huff emphasize, the genre of the diary presents the self in its daily repetitions as well as in contradictory positions in time (from moment to moment, day to day, year to year) - he stylizes his entries and manipulates how he appears in the text. ${ }^{38}$ The Diary retains the aura of seriality and non-retrospective immediacy. But this aura is the result of a carefully orchestrated strategy of writing, not something that comes automatically with the genre of the diary.

The Diary is unmistakably autobiographical, and yet it is not an autobiography, as defined by Lejeune: 'retrospective prose narrative written by a real person concerning his own existence, where the focus is his individual life, in particular the story of his personality'. ${ }^{39}$ According to Lejeune, the diary is close to autobiography in that it satisfies two important conditions that define autobiography, namely that 'the author (whose name refers to a real person) and the narrator are identical', and that 'the narrator and the principal

${ }^{36}$ Robert A. Fothergill, Private Chronicles: A Study of English Diaries (Oxford: Oxford University Press, 1974), p. 152.

37 Stuart Sherman, Telling Time: Clocks, Diaries, and English Diurnal Form 1660-1785 (Chicago: University of Chicago Press, 1996), p. 34.

${ }^{38}$ Felicity A. Nussbaum, The Autobiographical Subject: Gender and Ideology in EighteenthCentury England (Baltimore: Johns Hopkins University Press, 1989), p. 22; Cynthia Huff, 'Diaries and Diarists', in Victorian Britain: An Encyclopedia, ed. by Sally Mitchell (London: Routledge, 1988), pp. 215-16 (p. 215).

39 Philippe Lejeune, On Autobiography, ed. by Paul John Eakin, trans. by Katherine Leary (Minneapolis: University of Minnesota Press, 1989), p. 4. 
character are identical'. ${ }^{40}$ However, it does not meet two other criteria, which Lejeune admits are not as restrictive as the first two, but which nonetheless need to be fulfilled for a text to be considered an autobiography: to offer 'mainly retrospective [perspective]' and focus 'primarily on individual life, the genesis of the personality'. ${ }^{11}$ Although portions of the Diary are written in retrospect (what happened to the diarist today or over the past few days), many parts are discursive passages. And while this fact alone would not disqualify it from being an autobiography-Lejeune acknowledges that discourse has a place in autobiographical writing - it contains too many of these passages and no overarching retrospective prose narrative..$^{22}$ The genesis of the personality offered in the Diary is fragmented and indirect. Disseminated over many entries, disconnected pieces of the story of the diarist's life lack the clearly articulated narrative framework of a continuous development that we often associate with autobiographies.

Gombrowicz's Diary does not merely demonstrate the fact that the genre of the diary is more fragmentary and open-ended than autobiography-it deliberately accentuates this fact and exploits it. It uses stylization and mediation to undermine the transparency of the text, the correspondence between the diary and the diarist, and the identity between the author, the narrator, and the principal character, thereby destabilizing the ontological identity that we ascribe to writers of autobiographical genres and the contractual authority with which we endow their texts. If we regard the Diary as an illocutionary act, following Elizabeth W. Bruss's suggestion that we approach autobiographical genres as language acts which pertain not only to the propositional content of the text, but also to a declaration of attitude with respect to this content-in other words, if we look at the way and the force with which the Diary is presented as about its author-it is far from Lejeune's concept of the 'autobiographical pact'. ${ }^{43}$ According to Lejeune, autobiographical genres, including the diary, imply an agreement between the author and the reader that the name on the book refers to the author, narrator, and the main character, and that there is an identity between the three. ${ }^{44}$ This pact is not so much a product of extra-textual sincerity on the part of the writer and his intention, as it is a consequence of various signs of this intention in the text. For instance, The Confessions of Jean-Jacques Rousseau initiates the autobiographical pact in the title and in the name of the author on the book, develops it further in the preamble, and confirms it in the text by the use of 'Jean-Jacques' and

40 Ibid., p. 4.

41 Ibid., p. 5 (emphasis original).

42 Ibid.

43 Elizabeth W. Bruss, Autobiographical Acts: The Changing Situation of a Literary Genre (Baltimore: Johns Hopkins University Press, 1976), pp. 5-6.

44 Lejeune, On Autobiography, p. 12. 
'Rousseau'. ${ }^{45}$ Although Lejeune later consents to the criticism that not all readers accept this symbolic contract and might read the text differently from the way he suggests, he insists that all autobiographical genres try to eliminate fictionality by offering a guideline as to how they should be read. ${ }^{46}$

The Diary weakens the autobiographical pact by using irony, hyperbole, stylization, and flagrant self-manipulation. The text is presented as being about its author, but the identity of this author is constantly attacked. As a result, the intimacy that we find in most autobiographical writings is missing. Whenever the diarist reveals something about himself, this revelation does not lead to his more private and genuine self, not because he holds something back and keeps it to himself, but because he does not think that an autobiographical text can, or should, do this. When he notes, 'by taking you to the backstage of my being [kulisy mojej istoty], I force myself to retreat to an even more remote depth' ( $D$, p. 43), he is not suggesting that he retreats to protect his innermost self from the reader. The depth to which he refers is inaccessible even to him. The Diary is not concerned with self-description and self-analysis predicated on introspection. The diarist is not looking into himself to find out who he is so that he can then describe what he has found. Nor is he skipping the introspective step and turning directly to writing in order to externalize himself spontaneously and search for his true self in the image. But he is also not writing about himself, not fully knowing what he will say and not quite recognizing himself in the image, but nevertheless taking from it cues on who to be. The Diary is not a mirror in which the diarist recognizes or misrecognizes himself. Gombrowicz's technique of provocation and spoiling runs contrary to the principles of resemblance and recognition that one finds in most autobiographical writing.

The Diary capitalizes on the fact, as maintained by Lejeune, that the self and the universe created in diaries are fundamentally contingent and fragmented because the formal features of this genre (such as excessive repetitions, lack of coherence or relevance, and the unfinished quality of having no clear a priori end) prevent it from creating more integrated representations. ${ }^{47} \mathrm{But}$ unlike most diaries - which, according to Lejeune, settle into a narrow range of moulds in the composition of their entries in order to compensate for the genre's deficiency in unity and integration - the Diary expands this range and amplifies contingency. Whereas in most diaries the introspective turn into the self and the stylistically homogeneous entries alleviate contingency by endowing the diarist with a degree of intimacy and permanence, the stylistic idiosyncrasy, irony, and the various devices of self-manipulation in the Diary undermine the diarist's self-coherence and the text's intimacy, and turn

45 Ibid., p. 18.

46 Ibid., p. 126.

47 Lejeune, On Diary, p. 207. 
this autobiographical text into something other than a source of facts, an instrument of self-exegesis, or a model for who to become.

\section{The 'Diary' as a Transformative Text}

Writing a diary has traditionally been seen as a stabilizing practice, a periodic routine with the therapeutic effect of restoring one's sense of wholeness by putting one in touch with oneself. H. Porter Abbott argues that this element of restoration applies to fictional diaries as well, including structurally complex diary novels, such as Doris Lessing's The Golden Notebook, in which the several separate diaries of the protagonist that constitute the novel each reveal only one side of her schizophrenic personality, but the fact that she keeps different diaries for her different selves still has a soothing effect on her divided psyche. ${ }^{48}$ Autobiography, too, according to some critics, increases self-awareness and stabilizes the writer's self, because rather than just recollecting their past, autobiographers actively relate to it by selecting events from it, emphasizing some over others, and explaining links between them that were not immediately apparent, not even to the writers themselves. ${ }^{49}$ This therapeutic effect of stability and restoration is what Gombrowicz's Diary systematically undercuts. Instead of soliciting wholeness and coherence, the diarist undoes them. He provokes himself, debunks his habits, and offers different and often incompatible takes on events in his life with the goal of stimulating critical reflection on them and himself.

The diarist prompts reflection even in seemingly straightforward propositions. For instance, when he remarks that at the beginning human life is indefinite, a vague promise of the future when one will finally become a concrete person, but that when this future actually comes, one is suddenly too much of a concrete person, he does more than state a personal conviction. The self-denunciation that immediately follows-'Witold Gombrowicz, these two words, which I carried on myself, are now accomplished. I am. I am too much' ( $D$, p. 211) -is not, as Tomislav Z. Longinović argues, a declaration of Gombrowicz's belief that his identity has been fixed and that 'any further experiments with Form will always be contained within the realm of those "two words"'.50 Gombrowicz's admission that his struggle against Form has

${ }^{48}$ H. Porter Abbott, Diary Fiction: Writing as Action (Ithaca, NY: Cornell University Press, 1984), pp. 116-20.

49 Paul John Eakin, How Our Lives Become Stories: Making Selves (Ithaca, NY: Cornell University Press, 1999), p. x; Janet Varner Gunn, Autobiography: Toward a Poetics of Experience (Philadelphia: University of Pennsylvania Press, 1982), p. 8.

50 Tomislav Z. Longinović, 'I, Witold Gombrowicz: The Formal Imperative and the Power of Writing', in Gombrowicz's Grimaces: Form, Sexuality, Exile, ed. by Ewa Płonowska Ziarek (Albany: State University of New York Press, 1998), pp. 33-50 (p. 49). 
imposed on him a form of his own alters the situation it describes, as another self-reproach demonstrates:

In my old age life has become easier for me. I sail confidently between my contradictions and people listen to what I have to say. Yes, yes, I've dug my hole, I've played my part. I am a servant. Whose? Gombrowicz's. [...] To get rid of that other Gombrowicz, to compromise him, destroy him, would certainly be vivifying, but nothing is more arduous than to fight against one's own shell. ${ }^{51}$

Although eleven years have passed between the two self-criticisms, Gombrowicz raises the same issue and disregards ample evidence that, in fact, he did not remain locked in his fixed voice and kept contesting his shell, as texts such as Pornografia, Cosmos, and Operetta verify. In Gombrowicz's autobiographical texts, self-reproaches are not simple declarations of convictions or symptoms of depression and creative exhaustion. They are self-provocations that have the performative function of unsettling him and drawing out his artificialities.

The stimuli for critical reflection that Gombrowicz utilizes in the Diary differ from directives, such as those in Susan Sontag's diary. Sontag notes down prescriptions for herself: 'To smile less, talk less. Conversely, and most important, to mean it when I smile, and to believe what I say \& say only what I believe. ${ }^{52}$ Sontag wants to be a certain way and rereads her earlier entries to see where she stands with respect to her proclaimed goals. Her self-instructions aim at self-improvement. They are part of her plan to evolve in a certain direction, periodically assess her success, and propose new corrections to meet her objectives. The diary for her is an 'ego-building tool' of becoming someone specific and better. ${ }^{53}$ By contrast, for Gombrowicz the Diary is a means of becoming someone else. When he argues that for both the writer and the reader all literary writing must 'aspire to hone a spiritual life [zaostrzenia życia duchowego]' ( $D$, p. 10), he is not referring to an ideal self. This honing does not orient one towards an archetype of perfection, but towards something other than what one is at the moment. Spiritual life is a life of perpetual self-reinvention that takes place as one continually provokes oneself, reflects on oneself, and spoils one's established situation. For Gombrowicz, personal change is not a matter of concrete instructions and adjustments in response to them. Nor is it a matter of sudden realizations after which the writer is no longer the same as before. Instead, change is a slow process of self-transformation that occurs as the diarist writes about himself in the manner of provoking his artificialities and challenging his habits.

${ }^{51}$ Gombrowicz, A Kind of Testament, pp. 154-55.

52 Susan Sontag, Reborn: Early Diaries, 1947-1963, ed. by David Rieff (London: Penguin, 2009), p. 286.

53 Jerome Boyd Maunsell, 'The Writer's Diary as Device: The Making of Susan Sontag in Reborn: Early Diaries, 1947-1963', Journal of Modern Literature, 35 (2011), 1-20 (p. 11). 
Gombrowicz's concern with himself in the Diary pertains less to the self as a substance than to its temporal existence. The focal point of the text is not what one is (e.g. subjectivity, personality, psychological interiority, or soul), but how one lives and moves onward. The diarist's self-provocations are not an instrument of his self-expression, self-discovery, or ego-building. They are a form of engagement with his deformations that fosters self-transformation. In the Diary transformation is a result of a movement out and elsewhere, not of an introspective turn inward or towards something concrete. The ubiquitous theme of walking is emblematic of this movement elsewhere that is without telos and predetermined trajectory. The diarist walks, describes what he encounters, and follows the line of thought that these encounters stir in him. Above all, however, as Alicia Borinsky observes, he keeps moving on and away. ${ }^{54}$ When he finds something disagreeable, or exhausts the positive potential of an agreeable encounter, he moves on. Unlike the Surrealists, for whom walking was a way of releasing personal truths that are deeply buried within, Gombrowicz is a fast walker, which gives his walk a less meditative and a more diagnostic ambience. He does not look for unexpected encounters that reveal the unconscious contents of his mind. He searches for new things, critically confronts them, considers whether they are of interest, and departs as soon as they cease to be. This type of walk is an epitome of the existence advocated by Gombrowicz in the Diary, one which embraces the essential unfixedness of the self, its inevitable deformation, and the permanent flux of its temporal development.

Readers play an integral role in the transformative project of the Diary. They engage with the text as with any other, by considering its statements. This engagement is bolstered by the fact that the diarist frequently addresses his statements to the reader, as for instance in the above-cited advice on how to become an independent individual ('First, push away all the things that make everything easier [...]'). But the Diary incites readers' reflection also by virtue of less authoritative pronouncements, such as through irony, abrupt stylistic shifts, and the second voice, as we saw. These devices urge readers to be critical, attentive, and suspicious: that is, to exercise their independence and individuality while reading. Although the diarist states plainly that he prefers 'reluctant, distrustful, sober, sharp' ( $D$, p. 153) readers who take 'the trouble to inquire about the point at which my joke becomes seriousness; my irresponsibility, responsibility; my immaturity, maturity' ( $D$, p. 91), he does not tell readers what to do, assuming that his request will be followed or that only readers who comply with his vision will read the Diary. Rather, he deploys devices that encourage readers to interrogate critically what he says.

54 Alicia Borinsky, 'Gombrowicz's Tango: An Argentine Snapshot', in Exile and Creativity: Signposts, Travelers, Outsiders, Backward Glances, ed. by Susan Rubin Suleiman (Durham, NC: Duke University Press, 1998), pp. 143-62 (p. 158). 
But readers are an integral part of the Diary for another reason as well. Since Kultura printed Gombrowicz's entries regularly for a period of sixteen years, some readers wrote to Gombrowicz or published their reactions. Gombrowicz occasionally responded to these reactions in his new entries, thereby turning the Diary into a multi-way conversation: Gombrowicz with himself; readers with the text and themselves as they read it; some readers directly with Gombrowicz through correspondence and critical commentaries; and Gombrowicz with readers and himself as he answered them. This conversation, in which the spirit of provocation was further magnified whenever Polish nationalism and politics were debated, was renewed with each new entry. If, as Adam Zachary Newton argues, the Diary calls attention to the play of alterity and sameness by making it clear that the diarist is not known to himself because he constantly changes, readers of Kultura intensified this play by adding their own voices to it. ${ }^{55}$ In this original version of the text, the relationship between the writer and the reader was not a matter of the divide between the intimacy of the writer and the anonymous mass of readers, but a multidirectional exchange that shaped both the writer and the reader, because at least some of the readers also confronted their own artificialities and deformations as they critically reflected on the diarist's. At one point, Gombrowicz asserts his goal apropos the reader unequivocally: 'I wish to derail you. This is the rock that I am putting on your train tracks. To pull you out of the arrangement in which you find yourself' $(D$, p. 147).

Given this exchange between the diarist and his readers, current readers of the Diary as a single volume face new challenges. On the one hand, they have the advantage of being able to cover more text at one sitting than the original readers of Kultura, who were confined to what appeared in each issue. This allows current readers to be more cognizant of the stylistic shifts in writing and other formal aspects of the text. On the other hand, however, the new format is less conducive to Gombrowicz's conception of self-provocation and self-questioning as a recurrent and ongoing practice. Completing any autobiographical text, including segmented genres such as the diary and the self-portrait, and publishing it as a book imply retrospective consistency that is applied to the text as a whole. Different rearrangements and added features, such as prefaces and notes, endow the final product with a degree of coherence that it did not have at the time of writing. Although the Diary as a single volume retains the structure of dated entries that dispels any illusion of simultaneity and retrospective coherence among individual entries, the journal instalments of these entries, with no fixed end, no introduction, no addenda, and no index, were arguably more effective in preserving the text's evolution 
and performative power. These instalments and one's prolonged exposure to them were more likely to generate the slow transformation that Gombrowicz envisioned: 'I don't want to be like a wave breaking against a cliff, but, in my Diary, I want to be like water that soaks, drenches, saturates. ${ }^{56}$

\section{Reality, Sincerity, and Creativity in the 'Diary'}

Gombrowicz reveals that he is a passionate reader of diaries on account of 'a broth made of the taste of reality' ( $D$, p. 363) they contain. He believes that not only autobiographical genres, such as the diary, but all literature and art should comprise this broth and be 'well rooted in life' ( $D$, p. 29). Yet art must do more than imitate reality. It must reveal reality's previously unobserved aspects: 'Anything at all in art, everything in art, has the right to exist only insofar as it pertains to reality, to some new, sometimes shocking, reality which it makes accessible, alive, palpable' $(D$, p. 681). Art must be both creative and planted firmly in reality, and the problem with privileging one over the other is that both get lost. Deriding 'poets who are poets too much, and painters too devoted to painting' ( $D, \mathrm{p}$. 525), Gombrowicz argues that the artist 'who realizes himself inside art [który urzeczywistnia sie wewnatrz sztuki] will never be creative' ( $D$, p. 67), because his detachment from reality thwarts his creativity, which in turn reduces his art to mere grimaces $(D$, p. 528).

Against the empty art of grimaces, Gombrowicz posits the notion of sincerity [szczerość]. The maxim of literature, and autobiographical writing in particular, is to 'write in such a way that your reader will see you as a sincere man'. ${ }^{57}$ The Diary alludes to the notion of sincerity at first only indirectly, in a personal remark: 'I practically do not listen at all anymore to the meaning of the words, I listen only to how they are said' ( $D$, p. 36$)$. Later, this notion is explicitly connected with literary writing when Gombrowicz complains that there are so few writers about whom he can say, 'here begins genuine work of the spirit, definite, conscious, not opportunistic, calculated to endure' ( $D$, p. 254). Even Tonio Kröger, an autobiographical novella by Thomas Mann that Gombrowicz initially admired, falls prey to calculation: 'Mann's sincerity, integrity, and openness were just one more form of coquetry and one more way of forcing-under the guise of sincerity and even humility-others to acknowledge his own right to glory' ( $D$, p. 404). And yet, Gombrowicz is aware that sincerity in autobiographical texts is a tricky concept because by increasing candour when writing about oneself, one runs the risk of being pretentious and thus susceptible to grimaces. Hence the following dilemma and the proposed solution:

${ }_{56}$ Gombrowicz, A Kind of Testament, p. 120.

57 Ibid., p. 78. 
[The] Diary had to be sincere, but it could not be sincere. How could I solve the problem? The word, the loose, spoken word, has this consoling particularity: it is close to sincerity, not in what it shows [co okazuje] but in what it wants [czego chce] and in what it aims at [do czego dąży]. ${ }^{58}$

For Gombrowicz, sincerity in autobiographical texts is more about writing without pretence and self-delusions than about communicating objective truths about oneself. He deems most writers incapable of this kind of sincerity. Even the celebrated Polish writers Żeromski, Prus, Norwid, and Mickiewicz 'concealed something in themselves [coś $w$ sobie zataili] along the road of their development and, as a consequence of that concealment, were incapable of a comprehensive sincerity [wszechstronnej szczerości]' $(D, \mathrm{p} .11)$. Sincerity in writing is not a category of morality and ethically correct behaviour, but a manner of speaking and relating to oneself that repels affectation and formalism. Sincerity in writing brings out into the open the effects of deformation on oneself so that they can be inspected and exploited for one's development. In the Diary, sincerity is not a manifestation of the pure and unmediated self. Nor is it a means of getting at this self. Instead of a place of sincere confessions that lead to self-discovery, the Diary is a catalyst of becoming a subject of sincere speech that stimulates personal transformation.

If sincerity is about how one speaks rather than what one says, it is compatible with the technique of provocation. The principles of reality and sincerity espoused by Gombrowicz are not at odds with the principle of creativity and a creative style of writing about the self that he develops in the Diary. All these principles contribute to personal transformation, including the techniques of transposition, stylization, and genre experimentation that are usually associated with specifically literary writing and that are not in keeping with traditional expectations of autobiographical text. The Diary contains elements that can be regarded as 'literary'-'fictional', or at least improbable. It is now known, for instance, that some of the stories that Gombrowicz relates, particularly those that are more allegorical, such as the one about the beetles on the beach, were either invented or based on an actual event that was transformed and developed into hypothetical speculations. ${ }^{59}$ These types of 'story', together with other textual elements that can be regarded as

58 Ibid., p. 115 (translation modified).

59 The beetles on the beach occur in a narrative of Gombrowicz's afternoon siesta in a dreamlike landscape consisting of a long beach and steep mountains. His siesta is interrupted when he notices a beetle turned on its back by a wind storm. Gombrowicz rescues the animal, only to notice another one nearby. After rescuing it as well, he sees another one and then another. After a series of rescues, he realizes that he cannot rescue all of them because they stretch as far as he can see. He then faces the dilemma of when to stop and how to justify saving some but not others ( $D$, pp. 322-24). That this narrative is either invented or based on a real event and expanded to encourage allegorical interpretation is suggested by Jerzy Jarzębski, who discusses it not as a story, but as a 'parable' (przypowieść): Jerzy Jarzębski, 'Trudno być Bogiem', Teksty Drugie: teoria literatury, krytyka, interpretacja, 11 (2000), 68-77 (p. 74). 
literary, such as stylization and genre experimentation, separate the Diary from Gombrowicz's recently published 'secret diary' Kronos. The latter is closer to a traditional diary. It is highly context-specific and consists of unstylized catalogues of facts and itemized reports of events, mostly pertaining to Gombrowicz's intimate life, monetary concerns, and health problems. It is written in a curt and detached style, with often incomplete sentences, abbreviated words, question marks to indicate uncertainty, and underlined words to suggest likelihood: ' 1922 May-high school finals. Summer-(Sopot or) Małoszyce. Janusz's wedding?'60 But Kronos is no typical diary. As Michal Oklot documents, a large part of Kronos was written post factum, with entries for the period between 1922 and 1952 recorded after 1952 and backdated. ${ }^{61}$ The question is why Gombrowicz put down his recollections in diary form, and moreover, why he did so at the same time as he was writing the Diary and in such a different style.

Both Kronos and the Diary were commenced between 1952 and 1953 and carried on until 1969, the year of Gombrowicz's death. One answer to the question why Gombrowicz kept two separate diaries of such dissimilar kinds, with the former applying only the principle of reality and sincerity but not creativity, is that each served a different purpose. One was a private diary for personal affairs and the other a creative text with regular public feedback. This is certainly plausible, especially given the almost illegible handwriting in the manuscript of Kronos. However, the degree to which the factual, detached, and monotonous style in Kronos departs from the creative, imaginative, and diverse style of the Diary makes one wonder, as Jan Maciejewski remarks, whether it is the same person who wrote them. ${ }^{62}$ The morose and introvert Gombrowicz in Kronos has little in common with the lively and playful Gombrowicz of the Diary. This is not to suggest that the former is the real Gombrowicz behind all the provocations that he devises in the Diary. The Diary devotes too much attention to stylistic innovation and to formulating ideas about the self and Form for this text to serve as a mere screen for Gombrowicz, to be dispensed with in Kronos. Rather, Kronos should be seen as a provocation as well, albeit one that is indirect and contingent on the Diary. It is the disparity between the Diary and Kronos in terms of their content and form that makes the latter text part of Gombrowicz's autobiographical project of self-questioning, self-provocation, and self-repositioning. The marked absence of creativity, genre experimentation, and 'fictional' elements in Kronos stands out in contrast to the Diary. This absence throws into sharp relief the experimental nature of Gombrowicz's autobiographical project as a

60 Witold Gombrowicz, Kronos (Kraków: Wydawnictwo Literackie, 2013), p. 25 (my translation).

${ }^{61}$ Michal Oklot, 'Gombrowicz's Kronos: The Pornography of Aging', Slavonica, 19 (2013), 105-27 (p. 119).

${ }^{62}$ Jan Maciejewski, 'Witold Gombrowicz, Kronos', Pressje, 34 (2013), 196-97 (p. 197). 
whole, and of the Diary in particular. Gombrowicz writes about himself in different ways and styles, including the detached and factual style in Kronos of enumerating trivialities, such as what he bought and with whom he slept. These different ways and styles all contribute to his autobiographical project of unsettling himself, distancing himself from himself, and looking at himself from a variety of perspectives in order to move on and elsewhere.

The Diary corroborates the argument that even though Kronos is not creative and 'literary', it does not offer the real Gombrowicz. Towards the end of the Diary Gombrowicz suddenly realizes that once he is gone no one will be able to give an account of who he was because with each friend he was a different person. He ponders why he chose 'a way of living that was difficult to describe-a too-complicated system of masks' ( $D$, p. 674). Clearly, he did not think that Kronos would set the record straight, notwithstanding that he anxiously guarded the manuscript, as did his wife after he died. ${ }^{63}$ Kronos was part of the system of masks-part of Gombrowicz's autobiographical project of relating to himself and acting on himself by provoking himself. What is nonetheless curious, because it appears to go against the spirit of this very project, is the fact that Gombrowicz unexpectedly starts worrying about posterity and that he seems to believe in a correct self-image. If this is a moment of weakness, it is understandable, given Gombrowicz's serious health problems and anticipation of death that he frequently mentions in his late entries: 'There is more death in me than life. It is too late' $(D$, p. 674); 'I am nearing the end' ( $D, \mathrm{p} .735)$. But even this moment of weakness does not throw the entire project in question. If the Diary is a vehicle of transformation, to continue writing the same way until one day death stops the diarist's hand would be incongruous with its purpose. Not only is the act of doubting everything until the end, including one's chosen lifestyle, consistent with Gombrowicz's dialectical and critical attitude towards himself. The gesture of bringing the project actively to a close once the end is imminent also shows that the writer knows that he has little time to live and therefore no prospect of further self-transformation.

${ }^{63}$ Rita Gombrowicz, 'Nic więcej już nie chowam', interview with Agata Szwedowicz, 12 May 2013, PAP (Polska Agencja Prasowa) <http://culture.pl/pl/artykul/rita-gombrowicz-nic-wiecej-juznie-chowam-wywiad $>$ [accessed 2 November 2017]. 